\title{
Power Generation with Biomass from Coffee: A Literature Review, Current Trend and Scope for Future Research
}

\author{
Josepth A Rivera ${ }^{1, a}$, and Cesar H Ortega-Jimenez ${ }^{1,2,3, b, c, d}$ \\ ${ }^{1}$ Universidad Nacional Autónoma de Honduras (UNAH), Ingeniería Mecánica, Honduras \\ ${ }^{2}$ Universidad de Sevilla, Doctorado GENI, Sevilla, Spain \\ ${ }^{3}$ Universidad Tecnológica Centroamericana (UNITEC), Facultad de Postgrado, Honduras \\ ajosepth.rivera@unah.hn, ${ }^{b}$ cortega@unah.edu.hn, ${ }^{c}$ cortega@us.es, ${ }^{d}$ cortegaj@unitec.edu
}

\begin{abstract}
This paper takes on the current $R \& D$ on the use of biomass from coffee for electric power. This comprehensive literature review aims to synthesize, organize and structure on topics related to the use of solid waste, such as coffee pulp and husk for boilers for power plants. Initial available literature shows new technologies being implemented to transform and improve processes to obtain and generate this type of renewable energy. Using a systematic review, such coffee solid waste is presented as a bioenergy alternative to the sustainability of coffee processing plants. The results show the strengths and weaknesses of its use for energy, which may have significant impact on coffee producing countries, as it is one of the most booming industries of the countries from the equatorial tropics. Despite a wide range of applications of such coffee waste, we have identified few studies on the application of pyrolysis from such biomass power generation. This first review of literature on the subject has both practical implications about the current trend of coffee biomass as a means for generating energy, as well as it can be a basis for the scope for future research on the implementation and sustainability in coffee producing regions.
\end{abstract}

\section{Introduction}

Biomass has always been an important source of energy for mankind and today is estimated to contribute in the order 10 to $14 \%$ of global energy supply [1]. Although the potential for bioenergy is underrated because of the lack of information, coffee pulp and husk are residues from the production of the grain, which can be used as biomass, building coffee waste from agribusiness and food industry. However, since there is still scarce literature about coffee bioenergy, strengths and weaknesses about the process should be pointed out.

Both such sectors produce enormous quantities of coffee waste, both liquid and solid, since coffee is the second largest product traded in the world after oil [2]. Thus, on the one hand, given the continuous worldwide energy demand, sustainable production of coffee allows ways to exploit its disposal. On the other hand, with the development of new technologies described in the framework and proposition section, processes of generation have had a considerable improvement, where combustion of coffee and husk pulp are used. Such combustion is a complex phenomenon that involves simultaneous heat transfer and coupled mass with chemical reaction and fluid flow [3].

Thus, the pulp and husk of coffee would be a source of biomass that could be used as an additive to help combustion in a boiler using large volumes of waste heat [4]. However, it is necessary to review research in this area to find a suitable solution for using both forms of waste, since this organic product has a high caloric potential which can be used by pyrolysis for energy production. It is noteworthy that the literature on the generation of this type of renewable energy is very scarce. Hence, by means of thermally decomposing the feedstocks in a range of temperatures from 300 to $900{ }^{\circ} \mathrm{C}$, and in the presence of limited $\mathrm{O} 2$, pyrolysis results in the formation of three phase products [5]. To answer this objective, a framework where the chemical composition of the coffee waste is described, and the subsequent proposition of whether the use of pyrolysis may help to produce bioenergy in boilers, are both shown in Section 2. In Section 3, we explain the methodology used. Section 4 discusses the results obtained to respond such proposition, pointing out the strengths and weaknesses of using biomass from coffee waste. Finally, in last section (5) the conclusions of the paper are given.

\section{Framework and proposition}

Today, there is a strong political and social pressure to reduce pollution from industrial activities. So many countries worldwide are trying to adapt to this reality, changing their processes so that waste can be recycled and consequently, most large companies no longer consider waste as such, but as raw material for other processes [6]. Among these processes, bioenergy, such as transformation of biomass energy, comprises a large and diverse group of

Corresponding author: bcortega@unah.edu.hn 
sources and transformation processes with infrastructure requirements according to the end use desired energy give [7].

Biomass gasification gaseous products, pyrolysis of biomass and solid waste liquids, Anaerobic digestion of biomass to gaseous products, biomass conversion to methanol and ethanol for internal combustion engines [8]. When biomass is burned, or used after converting to other types of fuels, such as solid fuels (carbon), Liquids (ethanol) and gaseous (methane), the biomass carbon reacts with oxygen in air to form carbon dioxide released into the atmosphere is [9]. Since it is an organic material, we can find different types of biomass such as woody plants, grasses, aquatic plants, manure, coffee pulp, etc. [4]. Focusing on coffee pulp as biomass, Table 1 presents the calorific power of coffee[10], with an analysis of the percentage of coal, ash content and volatility [9]. The Table 1 shows that coffee has a high calorific value despite being a highly volatile matter, its use is discarded to burn in boiler due to its high content of ash and coal, and this would produce sedimentation in the boiler and would increase scheduled maintenance in any boiler.

Table 1. Calorific coffee waste.

\begin{tabular}{|c|c|c|c|c|}
\hline Fuel Type & $\begin{array}{c}\text { volatile } \\
\text { Matter }\end{array}$ & $\begin{array}{c}\text { Fixed } \\
\text { carbon }\end{array}$ & $\begin{array}{c}\text { Ash } \\
\text { content }\end{array}$ & [MJ/kg] \\
\hline $\begin{array}{c}\text { Coffee-parchment } \\
\text { husks }\end{array}$ & 76.50 & 20.70 & 2.80 & 18.2 \\
\hline
\end{tabular}

The standard measure of the energy content of a fuel is its calorific value, sometimes called heat of combustion. In fact, there are multiple values for heating this depending on whether measured enthalpy of combustion, the internal combustion energy and if, for a fuel containing hydrogen, the water produced is recorded in the vapor phase or phase condensed liquid [3]. Coffee pulp is essentially rich in carbohydrates, proteins and minerals (especially potassium) [11].

It also contains significant amounts of tannins, polyphenols and caffeine [12]. We try to explain biomass for use in boilers, describing characteristics that influence when designing plants for energy production. The pyrolysis is also described as an alternative for the use of coffee biomass.

\subsection{Biomass for boiler fuel.}

The biomass can be converted into fuel by numerous processes. The actual choice of a process depend on the type and amount of available biomass feedstock, the biomass can be burned directly as a fuel [9].

\subsection{Characteristics of common industrial fuels.}

A comparison of industrial fuels should consider the following characteristics of each fuel: a) cost per BTU as raw material, b) availability in any weather and in any international political climate; c) the complexity of the equipment found on the site to transport and burn fuel; d) problems associated with storage of the fuel; e) emissions from combustion; f) historical success of technology for boilers using this fuel. Consider coal, fossil fuel and natural gas in the light of these features [13].

\subsection{Pyrolysis of biomass.}

Pyrolysis is defined as the thermal destruction of organic matter in the absence of oxygen. Pyrolysis is based thermochemical process for converting biomass to useful fuel greater [14]. Biomass is heated in the absence of oxygen, or is partially burned in a limited oxygen supply, to produce a mixture rich gas hydrocarbon, a similar liquid oil and solid residue rich in carbon. The biomass then becomes liquid (bio-oil or bio-oil), coal gases and not condensable, acetic acid, acetone and methanol, heating the biomass at about $750 \mathrm{~K}$ in the absence of air. The process can be adjusted to favor the production of charcoal, pyrolytic oil, gas or methanol with an efficiency of $95.5 \%$ feed [15]. Further, coffee waste chemical composition is essential to design efficient systems for combustion. For instance, due to the high ash content that is left when coffee waste is burned without having been treated with any previous process, leaving a lot of sedimented waste in the boiler, and thus needing other methods to complement the combustion.

\subsection{Proposition.}

From this section, we state the following proposition on coffee husk and pulp: It is possible to convert the biomass of the coffee through a process of pyrolysis in a material for boilers, thus improving its combustion could also give another use to the crude resulting from this process.

\section{Research method}

To answer the objective of this paper, we developed the systematic review of the literature, by consulting mainly databases such as JSTOR, Emerald, Science Direct. Besides, Academy, Research Gate and Google Scholar were also used as alternative for country policy search in Paraguay, Brazil and Sri Lanka. The search strategy designed for a literature review from the selected documents published in journals and editorials published in the time interval from 1991 to 2019 . Our paper considered updated publications on whether the application of coffee waste may be an alternative energy source. Since the subject is still on the first stages of development, there is little to no information of conclusive scientific research.

We used the criteria inclusion and exclusion like can see in Fig. 1, starting 40 publications, it is important to stress out that we include documents published as journal papers, either in English or in Spanish. In the process of exclusion, we left out gray literature such as conference papers, and papers not published in journals. Then, based on the review of titles and abstracts, we selected the documents, by reviewing each paper, excluding those not containing renewable energy from biomass, resulting in eleven papers for more review. 


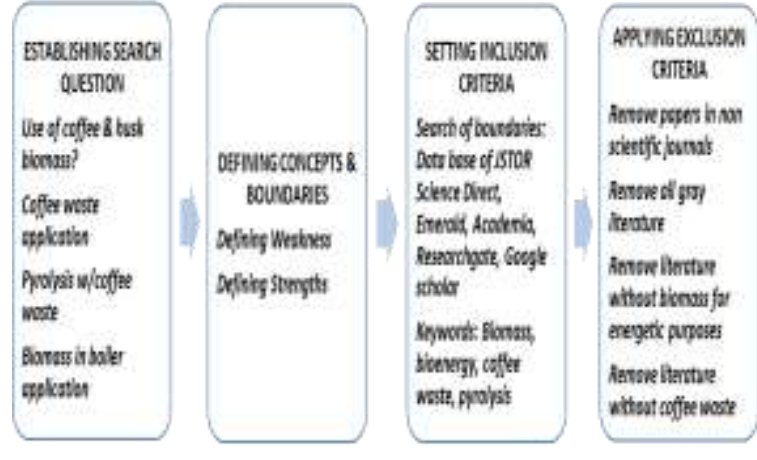

Fig.1 Methodology.

Finally, the pyrolysis method was searched as part of the papers, leaving only seven documents that included such method were finally considered to answer the proposition formulated and answering the objective of our paper. In Table 2, results are organized with the number of papers found according to their content and classified twofold, to find results and draw the conclusions for proposition in Section Framework and proposition: (1) application of biomass for energy generation; and (2) application of biomass using pyrolysis with coffee waste.

Table 2. Exclusion and inclusion of documents.

\begin{tabular}{|c|c|c|c|}
\hline $\begin{array}{c}\text { Topic } \\
\text { Document }\end{array}$ & $\begin{array}{c}\text { Application of } \\
\text { biomass to } \\
\text { generate } \\
\text { energy }\end{array}$ & $\begin{array}{c}\text { Application } \\
\text { of biomass } \\
\text { pyrolysis } \\
\text { coffee pulp }\end{array}$ & $\begin{array}{c}\text { Citations } \\
\text { in the } \\
\text { analysis }\end{array}$ \\
\hline $\begin{array}{c}\text { Biomass } \\
\text { coffee waste }\end{array}$ & 21 papers & 2 papers & 2 papers \\
\hline $\begin{array}{c}\text { Bioenergy } \\
\text { coffee waste } \\
\text { boiler }\end{array}$ & 5 papers & 1 paper & 2 papers \\
\hline $\begin{array}{c}\text { Coffee } \\
\text { biomass } \\
\text { boiler }\end{array}$ & 8 papers & 2 papers & 3 papers \\
\hline
\end{tabular}

\section{Discussion of literature review}

Based on the review of literature from Table 2 we defined and divided the strengths and weaknesses of transforming biomass from residues of coffee. Thus, the research leads to the following discussion of results, from Table 3 . The selection of such papers identifies the main findings in the review on the use of coffee biomass, by means of pyrolysis.

While the papers yellow highlighted are the ones that serve to clarify the topics related to the research, the papers blue highlighted are those of greater relevance to answer the proposition.

As far as discussion of the review, we next present the strength and the weakness, identifying their strengths and weaknesses we can see the feasibility of their use and so answer the proposal.

\subsection{Strengths of coffee biomass.}

Completely burnt, the amount of carbon dioxide produced is equal to the amount extracted from the atmosphere during the growth stage. Hence, biomass is available renewably either through natural processes or may be available as a byproduct of human activities, such as organic waste pyrolysis biomass conversion may have an efficiency of up to $70 \%$.[1]. These policies are focused on your biomass use and the level of $\mathrm{CO} 2$ emissions content but obtaining is regenerative. The biomass, economically viable, has reported in several oil-importing countries Paraguay [16], Sri Lanka [17], Brazil [18]. However, the feasibility of this technology is very specific location and must make a detailed assessment before recommending for any country or location, as described by JK Laichena [19]. Biomass to bioenergy is making progress and significant technological advances in recent decades, but there are obstacles and challenges to be addressed to reduce cost and reliability, expansion and integration, and investment to achieve bio-sustainable economy HM Junginger [20]. The future of biomass in boilers depends on the development of fossil fuel markets and market decisions. There are countries, such as Malaysia, India and the United States already implementing the use of biomass for energy production [19].

Table 3. Results of the literature review

\begin{tabular}{|l|l|l|l|}
\hline Author & Year & Reference & $\begin{array}{l}\text { Contribution to } \\
\text { answer proposition }\end{array}$ \\
\hline $\begin{array}{l}\text { McKendry } \\
\text { P }\end{array}$ & 2002 & {$[1]$} & \\
\hline Saidur R & 2011 & {$[9]$} & \\
\hline Uddin MN & 2019 & {$[21]$} & \\
\hline $\begin{array}{l}\text { JK } \\
\text { Laichena }\end{array}$ & 1991 & {$[19]$} & \\
\hline $\begin{array}{l}\text { HM } \\
\text { Junginger }\end{array}$ & 2019 & {$[20]$} & \\
\hline Saenger M & 2001 & {$[10]$} & \\
\hline Demirbas A & 2011 & {$[15]$} & \\
\hline
\end{tabular}

\subsection{Weaknesses of coffee biomass.}

One of the reasons for the low level of use of coffee waste as fuel for direct combustion is the lack of sufficient information on the characteristics of combustion and emission of waste, as stated by Saenger M [10]. Such information would be useful for the design and efficient operation of combustion systems for coffee husks and the coffee pulp being this matter for biomass studies. Further, HM Junginger exposes that biomass to bioenergy needs to focus on reduction of emissions, which are currently too high [20]. However, by using pyrolysis, such emissions will be less. On the other hand, the future of biomass in boilers depends on the development of fossil fuel markets and policy decisions these policies are focused on your biomass use and the level of $\mathrm{CO} 2$ emissions. As Saidur R [9] says, all these policies need to promote the use of biomass in different sectors by setting some standards, fiscal policies, taxation and financing.

Besides, biomass has a calorific value significantly lower than most of the coal. This is partly due to higher moisture content and, in part, to the high oxygen content 
and got more emissions, but obtaining is regenerative this is respond by Demirbas A [15] .

\subsection{Answer to proposition.}

The strengths and weaknesses of the application of coffee biomass show that such waste is subject to policies for the implementation in each country. The implementation of pyrolysis can turn such material into a fuel that would be an excellent additive to other biomass, thus improving combustion. Besides, after using pyrolysis, one can refine the product to make biodiesel as the kinematic viscosity of oil residues coffee biodiesel with $5.16 \mathrm{~mm} 2 / \mathrm{s}$, the oxidation stability of $4 \mathrm{~h}$, the cetane number of 53 (i.e., this is higher than diesel fuel with a value between 45 and 55). However, these results are within the specified limit, either according to ASTM D6751 or EN 14214 (1.9-6 mm2 / s) standards.[21]. Therefore, we can accept the Proposition in Section 2 of our paper.

\section{Conclusions}

In this paper, the combustion mechanisms of coffee waste, using pyrolysis combustion techniques, the highlights of the literature review are shown next. First, pyrolysis biomass conversion may have an efficiency of up to $70 \%$. In addition, the bio-crude can be used in engines and turbines, as well as feedstock for refineries. There are some interesting trends, especially regarding the effect of the rate of net heating and temperature, as pyrolysis increases the heating rate or temperature net required.

Second, there is need for more research in this area to find a suitable solution for low sintering properties of coffee husks. Techniques such as the use of additives, suitable design of the oven and co-fired with coal to be tested on a larger scale and in situations of actual combustion, are opportunities for future research. One of the main limitations of the use of coffee waste (pulp and husk) as bioenergy is that widely used as a fertilizer, because of its rich nutrients. Furthermore, since it is a seasonal product, it requires large spaces of storage as gathering centers, which must be free of humidity. This also implies the needs for transportation and logistics to these centers. This presents an opportunity for future research on the supply chains for coffee.

Finally, our research is a first approximation as a literature review about bioenergy with coffee waste with practical implications for managers, engineers and practitioners that consider coffee pulp and husk more than merely waste and can thus reuse it as a form sustainable development for adding with practical implications for adding value on coffee byproducts.

\section{Acknowledgments}

The authors wish to acknowledge the support of UNAH.

\section{References}

[1] McKendry P. Energy production from biomass (part 1): overview of biomass. Bioresour Technol 2002;83:37-46.

doi:10.1016/S0960-8524(01)00118-3.

[2] Nabais JMV, Nunes P, Carrott PJM, Ribeiro

Carrott MML, García AM, Díaz-Díez MA.

Production of activated carbons from coffee endocarp by $\mathrm{CO} 2$ and steam activation. Fuel Process Technol 2008;89:262-8.

doi:10.1016/j.fuproc.2007.11.030.

[3] Jenkins B., Baxter L., Miles T., Miles T.

Combustion properties of biomass. Fuel Process Technol 1998;54:17-46.

doi:10.1016/S0378-3820(97)00059-3.

[4] Adams M, Ghaly AE. Maximizing sustainability of the Costa Rican coffee industry. J Clean Prod 2007;15:1716-29.

doi:10.1016/J.JCLEPRO.2006.08.013.

[5] Review of fast pyrolysis of biomass and product upgrading. Biomass and Bioenergy 2012;38:6894. doi:10.1016/J.BIOMBIOE.2011.01.048.

[6] Mussatto SI, Dragone G, Roberto IC. Brewers' spent grain: generation, characteristics and potential applications. J Cereal Sci 2006;43:1-14. doi:10.1016/J.JCS.2005.06.001.

[7] Valdez-Vazquez I, Acevedo-Benítez JA, Hernández-Santiago C. Distribution and potential of bioenergy resources from agricultural activities in Mexico. Renew Sustain Energy Rev 2010;14:2147-53. doi:10.1016/J.RSER.2010.03.034.

[8] DEMIRBAS A. Current Technologies for the Thermo-Conversion of Biomass into Fuels and Chemicals. Energy Sources 2004;26:715-30. doi:10.1080/00908310490445562.

[9] Saidur R, Abdelaziz EA, Demirbas A, Hossain MS, Mekhilef S. A review on biomass as a fuel for boilers. Renew Sustain Energy Rev 2011;15:226289. doi:10.1016/J.RSER.2011.02.015.

[10] Saenger M, Hartge E-U, Werther J, Ogada T, Siagi Z. Combustion of coffee husks. Renew Energy 2001;23:103-21. doi:10.1016/S0960-1481(00)00106-3.

[11] Murthy PS, Madhava Naidu M. Sustainable management of coffee industry by-products and value addition-A review. Resour Conserv Recycl 2012;66:45-58. doi:10.1016/J.RESCONREC.2012.06.005.

[12] Bressani R, Estrada E, Jarquin R. Pulpa y pergamino de cafe. I. Composicion quimica $y$ contenido de aminoacidos de la proteina de la pulpa. Turrialba 1972.

[13] Capehart BL (Barney L., Turner WC, Kennedy WJ. Guide to energy management. Fairmont Press; 2006.

[14] Balat M. Mechanisms of Thermochemical Biomass Conversion Processes. Part 1: Reactions of Pyrolysis. Energy Sources, Part A Recover Util Environ Eff 2008;30:620-35. doi:10.1080/15567030600817258.

[15] Demirbas A. Combustion characteristics of different biomass fuels. Prog Energy Combust Sci 2004;30:219-30. 
doi:10.1016/J.PECS.2003.10.004.

[16] Paraguay (2012) - Policy and Regulatory Overviews - Clean Energy Information Portal reegle n.d.

[17] Authority TSLSE, Consulting PA, Group PSLBPW. Policies and Regulations Affecting Biomass-Related Energy Sector Development in Sri Lanka n.d. doi:10.2307/resrep00096.

[18] Biernaski I, Silva CL, Biernaski I, Silva CL. Main Variables of Brazilian Public Policies on Biomass use and Energy. Brazilian Arch Biol Technol 2018;61. doi:10.1590/1678-4324-smart-2018000310.

[19] Laichena JK. Biomass Fuel in Kenya: Availability and the Potential for Gasification. Energy Explor Exploit 1991;9:405-21. doi:10.1177/014459879100900606.

[20] Junginger HM, Mai-Moulin T, Daioglou V, Fritsche U, Guisson R, Hennig C, et al. The future of biomass and bioenergy deployment and trade: a synthesis of 15 years IEA Bioenergy Task 40 on sustainable bioenergy trade. Biofuels, Bioprod Biorefining 2019;13:247-66. doi:10.1002/bbb.1993.

[21] Uddin MN, Techato K, Rasul MG, Hassan NMS, Mofijur M. Waste coffee oil: A promising source for biodiesel production. Energy Procedia 2019;160:677-82. doi:10.1016/J.EGYPRO.2019.02.221. 